University of Nebraska - Lincoln

DigitalCommons@University of Nebraska - Lincoln

Publications from USDA-ARS / UNL Faculty

U.S. Department of Agriculture: Agricultural

Research Service, Lincoln, Nebraska

1997

\title{
Middle Holocene aeolian activity on the High Plains of west- central Kansas
}

C. G. Olsen

USDA-NRCS

W. D. Nettleton

USDA-NRCS

D. A. Porter

Kansas State University

B. R. Brasher

USDA-SCS

Follow this and additional works at: https://digitalcommons.unl.edu/usdaarsfacpub

Olsen, C. G.; Nettleton, W. D.; Porter, D. A.; and Brasher, B. R., "Middle Holocene aeolian activity on the High Plains of west-central Kansas" (1997). Publications from USDA-ARS / UNL Faculty. 1426.

https://digitalcommons.unl.edu/usdaarsfacpub/1426

This Article is brought to you for free and open access by the U.S. Department of Agriculture: Agricultural Research Service, Lincoln, Nebraska at DigitalCommons@University of Nebraska - Lincoln. It has been accepted for inclusion in Publications from USDA-ARS / UNL Faculty by an authorized administrator of DigitalCommons@University of Nebraska - Lincoln. 


\title{
Middle Holocene aeolian activity on the High Plains of west-central Kansas
}

\author{
C.G. Olson, ${ }^{1}$ W.D. Nettleton, ${ }^{1}$ D.A. Porter ${ }^{2}$ and B.R. Brasher ${ }^{3}$ \\ $\left({ }^{1}\right.$ USDA-NRCS, Lincoln, Nebraska, 68508, USA; ${ }^{2}$ Agronomy Department, Kansas \\ State University, Manhattan, KS, USA; ${ }^{3} U S D A-S C S$, retired)
}

Received 30 May 1996; revised manuscript accepted 19 February 1997

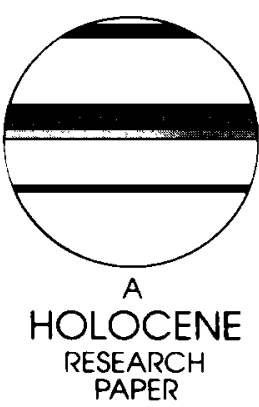

\begin{abstract}
The uppermost surficial stratigraphic unit south of the Arkansas River in the Kansas High Plains is a previously unidentified middle Holocene or younger loess. The unit fits both a loess-thickness and a particlesize model for loess distribution with increasing distance from source. A soil immediately below this unit is radiocarbon dated 6000 to 6700 years $\mathrm{BP}$. The radiocarbon ages indicate that the loess unit is younger than the commonly reported ranges for Bignell Loess in the Great Plains and demonstrate a need for re-examining Holocene loess stratigraphy of the Great Plains. In some locations closest to the Arkansas valley source, this middle Holocene unit is overlain by, or interfingers with, dune sands. The presence of these aeolian sands indicates that, following a period of relative landscape stability and soil development, a shift toward a middleHolocene climate in which aeolian processes dominated occurred about 6000 years ago on the High Plains of west-central Kansas.
\end{abstract}

Key words: Loess, aeolian activity, palaeosol, radiocarbon dating, loess-distribution model, middle Holocene, High Plains, Kansas.

\section{Introduction}

In the High Plains of Kansas south of the Arkansas River and north of the Cimarron River, few detailed studies assess the character of the surficial sediments. Thorp and Smith (1952) provided the first comprehensive reconnaissance maps of this area, based in part on Smith's field work in the 1930s and 1940s. Some of the site data used to prepare the 1952 map are recorded in more detail in Smith (1940). The soil survey reports for Finney (Harner et al., 1965), Gray (Tomasu and Roth, 1968), and Haskell (Hamilton et al., 1968) Counties, Kansas, also provide background information on the soils and surficial sediments here. More recently the Kansas Geological Survey has provided a reconnaissance state map (Ross, 1991), and Johnson and Arbogast (1993) completed a surficial geologic map of Finney County. These studies describe the type of sediment present, but the source and distribution are not addressed. The objectives of the present study are: 1) to characterize the upper surficial stratigraphic units in order to compare these findings with the reconnaissance maps; and 2) to apply a loess-distribution model to the uppermost surficial unit in the study area to confirm its aeolian origin.

This study encompasses the region in west-central Kansas from the Arkansas River to the Cimarron River on the eastern edge of the High Plains. The High Plains is a nearly level largely undissected surface capped by the Pliocene Ogallala Formation overlain by thick unconsolidated surficial sediments of Quaternary age. Exposures in the surficial sediments, other than occasional borrow pits and railroad cuts, are rare. In our study area, coring provided the only method for subsurface stratigraphic investigation. The surficial maps of Thorp and Smith (1952) and Ross (1991) show our study area as primarily loess-covered. Dune fields are shown adjacent to the Arkansas River and south of the Cimarron River. Thorp and Smith (1952) term the loess Wisconsinan estimate

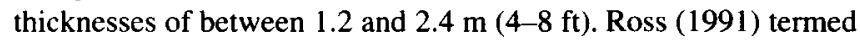
it 'thin undifferentiated Holocene and Pleistocene loess'. Figure 1, modified from Thorp and Smith (1952), illustrates the surface stratigraphy for the study area. From auger borings as deep as

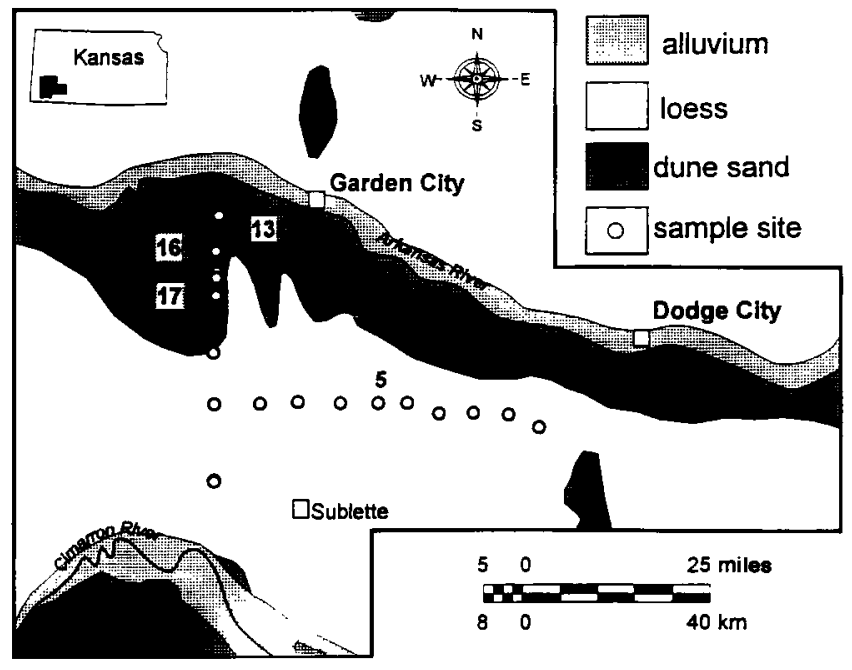

Figure 1 Surficial geologic map of field area and locations of sample sites. Geology is modified from Thorp and Smith (1952). 
$21 \mathrm{~m}(70 \mathrm{ft})$, Simonett (1960) constructed a general stratigraphic section $27 \mathrm{~km}$ (17 miles) long, southward from the Arkansas River. Dune sand 1-18 m (3-60 ft) thick overlies 1-3 m (3-10 ft) of loess, which Simonett termed 'lower Peoria Loess' based on fossil evidence, over pre-Illinoian weathered sands and gravels. At a distance of $16 \mathrm{~km}$ ( 10 miles) from the Arkansas River, Simonett

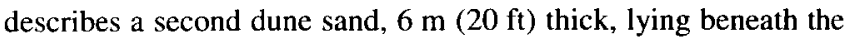
lower Peoria Loess and just above buried Wisconsinan and Illinoian terraces. We identified similar sequences of upper stratigraphic units, but did not penetrate the terrace sediments or weathered sand and gravel, as our coring was limited generally to depths of less than $6 \mathrm{~m}$. Additionally, we identified a fine-grained deposit at the surface that seems to be stratigraphically equivalent to, or younger than, some of the dune sands augered by Simonett (1960). This uppermost, fairly continuous silty deposit, whose lower boundary is easily recognized in the field only when a palaeosol is present beneath, is the unit investigated in this study. Is it a loess or alluvium, and how does it relate to the Bignell Loess or other Holocene stratigraphic units? Prior evidence for Bignell Loess in this part of Kansas is lacking.

\section{Materials and methods}

Two major traverses were sampled between the Arkansas and the Cimarron Rivers. Nine sites were on an east-west traverse along the main divide between the Arkansas and Cimarron Rivers from about $21 \mathrm{~km}$ (13 miles) south of Dodge City, Kansas, to about $19 \mathrm{~km}$ (12 miles) northwest of Sublette, Kansas (Figure 1). Eight sites were sampled in a north-south traverse at about the $101^{\circ} \mathrm{W}$ longitude, beginning near Garden City to $12.9 \mathrm{~km}$ ( 8 miles) north of Satanta, Kansas. With the exception of three sites on the northsouth traverse, all sites were located approximately $8 \mathrm{~km}$ ( 5 miles) apart. Two sets of cores were extracted from each site with a Giddings hydraulic soil probe, and continuous cores were sampled and described according to methods in the Soil Survey Manual (Soil Survey Staff, 1951; 1993). Stratigraphy at each site was documented along with the soil descriptions and correlated among sites by field descriptions and later confirmed by analyses of particle-size separates. Laboratory analyses were completed following the standard methods of the Natural Resources Conservation Service (Soil Survey Laboratory Staff, 1992). The upper, most widely distributed stratigraphic unit was used to test the loessdistribution model. Particle size, calculated on clay-free basis, was used for determinations in the loess-distribution model. Weightedaverage values were calculated for the very fine sand, coarse-silt, and fine-silt fractions. These values were plotted against distance from a projected valley source area. Radiocarbon analyses of whole soil were determined by accelerator mass spectrometry (AMS) through Beta Analytic, Inc. Ages referred to in this study are in radiocarbon years.

\section{Results and discussion}

\section{Loess-distribution model}

Loess may be defined simply as windblown silt. Loess deposits and their distribution have unique characteristics that distinguish them from other silty deposits such as alluvium. Among the characteristics are the consistent relationships between the source, the distribution, and thickness, which compose parts of a loessdistribution model.

Loess-distribution models have been developed for the thick loess units of the mid-continent USA. Among the more widely cited are those of Smith (1942) in Illinois and Ruhe (1969) in Iowa. Olson and Ruhe (1979) presented a similar model for southwestern Indiana. Ruhe (1973) comprehensively reviewed the literature relevant to loess dispersion for the upper Mississippi Valley. Handy (1976) presented a theoretical mathematical treatment for loess distribution by variable winds in Iowa. To the west on the Great Plains, Frye and Fent (1947), Swineford and Frye (1951), and Frye and Leonard $(1951 ; 1952)$ provided background on loess in Kansas but did not employ specific models to describe its distribution. In Texas, Seitlheko (1975) describes particle-size distribution of surficial sediments from a Pecos River valley source.

The first step in this study was to separate the uppermost stratigraphic unit from the underlying units. In this region where multiple loess units are present (Frye and Fent, 1947; Frye and Leonard, 1951; 1952), separation of Late Wisconsinan loesses from Holocene loess units has been limited to those locations where a palaeosol is present. This limitation has restricted recognition of these individual loess units to specific sites or extremely small areas. In Kansas, separation of loess units is complicated by the probability that many Holocene units, including the Bignell Loess, are reworked and derived from older materials of the same composition, principally the Late Wisconsinan Peoria Loess (Feng, 1991; Johnson, 1993). Without the presence of a palaeosol at the contact of these units, separation of younger, Holocene loess units from older, Peoria Loess is extremely difficult.

In this study area, palaeosols were described at seven sites beneath the Holocene unit. At the remainder of the sites, palaeosols either were not described or were not located in the proper stratigraphic position for comparison. At many sites, the base of the Holocene unit could not be determined from field evidence. The only field clue was that measured thicknesses for the Holocene unit were excessive when compared with sites where underlying palaeosols were present. A more reliable means of identifying the surficial Holocene unit was needed.

The most effective way found to separate stratigraphic units in this study without the benefit of stratigraphically continuous palaeosols was to calculate the particle size on a clay-free basis. The fine silt, coarse silt, very fine sand, and fine sand distributions were examined for each sample site. Where the difference in particle-size percentage between samples from adjacent depth intervals was greater than 3 or $4 \%$ for each fraction or were increased or reduced abruptly by two- or threefold, a stratigraphic break was inferred to be present. For example, Table 2 shows the depths and particle size calculated on a clay-free basis for the first $3 \mathrm{~m}$ at site 5. The first stratigraphic break was determined at a depth of $127 \mathrm{~cm}$. Note that where the profile distributions of very fine sand and fine silt change significantly, the very fine sand decreases and the fine silt increases abruptly. The fine sands are reduced by nearly one-half and the coarse silts increased only by a few $\%$. The $127-\mathrm{cm}$ value represents the thickness of the uppermost stratigraphic unit for site 5 . The thickness of the uppermost stratigraphic unit was determined for each sample location in the same manner. Thicknesses thus obtained were then checked against field textures and descriptions to ensure that the stratigraphic breaks were reliably interpreted.

In establishing potential source areas for testing the loess-distribution model in this study, a series of locations in the Arkansas and Cimarron River valleys were evaluated. Field estimates of textures from the top $64 \mathrm{~cm}$ ( 25 in) were examined along the two sampling traverses (Table 1). Surface textures for the dune-sand sites of the northern $48 \mathrm{~km}$ (30 miles) of the north-south traverse closest to the Arkansas River are coarse, gradually fining with distance away from the Arkansas River and toward the Cimarron River. Surface textures for all sites along the east-west traverse and for those along the southern $32 \mathrm{~km}$ ( 20 miles) of the northsouth traverse are silt loam or silty-clay loam. Surface textures for the six sites closest to the Arkansas River on the north-south traverse are increasingly coarser to the north. If we accept the principles of aeolian sedimentation as described by Bagnold 
Table 1 Surface textures measured in the field at each sample site; the upper $60-65 \mathrm{~cm}$ are tabulated with horizon designation and thickness

\begin{tabular}{|c|c|c|c|c|}
\hline Site & $\begin{array}{l}\text { Depth } \\
(\mathrm{cm})\end{array}$ & Horizon $†$ & $\begin{array}{l}\text { Distance } \\
(\mathrm{km})\end{array}$ & Surface texture ${ }^{*} \dagger$ \\
\hline 15 & $\begin{array}{r}0-13 \\
13-36 \\
36-66\end{array}$ & $\begin{array}{l}\text { Ap } \\
\text { Bt1 } \\
\text { Bt2 }\end{array}$ & 135.3 & $\begin{array}{l}\text { sicl } \\
\text { sicl } \\
\text { sic }\end{array}$ \\
\hline 1 & $\begin{array}{r}0-12 \\
12-26 \\
26-44 \\
44-60\end{array}$ & $\begin{array}{l}\text { Ap } \\
\text { BA } \\
\text { Bt1 } \\
\text { Bt2 }\end{array}$ & 122.0 & $\begin{array}{l}\text { sil } \\
\text { sil } \\
\text { sicl } \\
\text { sicl }\end{array}$ \\
\hline 2 & $\begin{array}{r}0-10 \\
10-18 \\
18-28 \\
28-36 \\
36-53 \\
53-64\end{array}$ & $\begin{array}{l}\text { Ap } \\
\text { A } \\
\text { BA } \\
\text { Bt1 } \\
\text { Bt2 } \\
\text { Bck }\end{array}$ & 115.5 & $\begin{array}{l}\text { sil } \\
\text { sil } \\
\text { sicl } \\
\text { sicl } \\
\text { sicl } \\
\text { sicl }\end{array}$ \\
\hline 3 & $\begin{array}{r}0-13 \\
13-23 \\
23-33 \\
33-46 \\
46-66\end{array}$ & $\begin{array}{l}\text { Ap } \\
\text { A } \\
\text { BA } \\
\text { Bt } 1 \\
\text { Bt2 }\end{array}$ & 108.0 & $\begin{array}{l}\text { sil } \\
\text { sil } \\
\text { sil } \\
\text { sicl } \\
\text { sicl }\end{array}$ \\
\hline 4 & $\begin{array}{r}0-13 \\
13-23 \\
23-36 \\
36-53 \\
53-64\end{array}$ & $\begin{array}{l}\text { Apl } \\
\text { Ap2 } \\
\text { BA } \\
\text { Bt1 } \\
\text { Bt2 }\end{array}$ & 99.0 & $\begin{array}{l}\text { sil } \\
\text { sic } \\
\text { sicl } \\
\text { sicl } \\
\text { sicl }\end{array}$ \\
\hline 5 & $\begin{array}{r}0-15 \\
15-36 \\
36-48 \\
48-58 \\
58-64\end{array}$ & $\begin{array}{l}\text { Ap } \\
\text { Bt1 } \\
\text { Bt2 } \\
\text { Bt3 } \\
\text { Bt4 }\end{array}$ & 89.3 & $\begin{array}{l}\text { sil } \\
\text { sicl } \\
\text { sicl } \\
\text { sicl } \\
\text { sicl }\end{array}$ \\
\hline 6 & $\begin{array}{r}0-13 \\
13-25 \\
25-61\end{array}$ & $\begin{array}{l}\mathrm{Ap} \\
\mathrm{Bw} \\
\mathrm{Bk}\end{array}$ & 83.0 & $\begin{array}{l}\text { sicl } \\
\text { sicl } \\
\text { sicl }\end{array}$ \\
\hline 7 & $\begin{array}{r}0-13 \\
13-36 \\
36-46 \\
46-66\end{array}$ & $\begin{array}{l}\text { Ap } \\
\text { Bt } \\
\text { Btk } \\
\text { Btk }\end{array}$ & 72.7 & $\begin{array}{l}\text { sil } \\
\text { sicl } \\
\text { sicl } \\
\text { sicl }\end{array}$ \\
\hline 8 & $\begin{array}{r}0-10 \\
10-18 \\
18-33 \\
33-48 \\
48-69\end{array}$ & $\begin{array}{l}\text { Apl } \\
\text { Ap2 } \\
\text { Bw } \\
\text { Bck } \\
\text { C1 }\end{array}$ & 64.1 & $\begin{array}{l}\text { sil } \\
\text { sil } \\
\text { sil } \\
\text { sil } \\
\text { sil }\end{array}$ \\
\hline 9 & $\begin{array}{r}0-10 \\
10-23 \\
23-30 \\
30-38 \\
38-61\end{array}$ & $\begin{array}{l}\text { Ap1 } \\
\text { Ap2 } \\
\text { Bt1 } \\
\text { Bt2 } \\
\text { Btk }\end{array}$ & 61.9 & $\begin{array}{l}\text { sil } \\
\text { sicl } \\
\text { sicl } \\
\text { sicl } \\
\text { sil }\end{array}$ \\
\hline 10 & $\begin{array}{r}0-15 \\
15-30 \\
30-56 \\
56-64\end{array}$ & $\begin{array}{l}\mathrm{Ap} \\
\mathrm{Bw} \\
\mathrm{BC} \\
\mathrm{C}\end{array}$ & 57.5 & $\begin{array}{l}\text { sil } \\
\text { sil } \\
\text { sil } \\
\text { sil }\end{array}$ \\
\hline 11 & $\begin{array}{r}0-10 \\
10-33 \\
33-61\end{array}$ & $\begin{array}{l}\text { A } \\
\text { Bt } \\
\text { 2Btkb }\end{array}$ & 53.2 & $\begin{array}{l}\text { fsl } \\
\text { scl } \\
\text { sicl }\end{array}$ \\
\hline 16 & $\begin{array}{r}0-20 \\
20-38 \\
38-64\end{array}$ & $\begin{array}{l}\mathrm{A} \\
\mathrm{AC} \\
\mathrm{Cl}\end{array}$ & 52.6 & $\begin{array}{l}\text { Is } \\
\text { ls } \\
\text { s }\end{array}$ \\
\hline 17 & $\begin{array}{r}0-13 \\
13-25 \\
25-51 \\
51-64\end{array}$ & $\begin{array}{l}\mathrm{A} \\
\mathrm{AC} \\
\mathrm{C} 1 \\
\mathrm{C} 2\end{array}$ & 53.0 & $\begin{array}{l}\text { vfsl } \\
\text { vfsl } \\
\text { vfsl } \\
\text { ls }\end{array}$ \\
\hline 12 & $\begin{array}{r}0-10 \\
10-28 \\
28-64\end{array}$ & $\begin{array}{l}\mathrm{A} \\
\mathrm{AC} \\
\mathrm{C} 1\end{array}$ & 50.0 & $\begin{array}{l}\text { Ifs } \\
\text { fs } \\
\text { fs }\end{array}$ \\
\hline 13 & $\begin{array}{r}0-15 \\
15-28 \\
28-64\end{array}$ & $\begin{array}{l}\mathrm{A} \\
\mathrm{AC} \\
\mathrm{C} 1\end{array}$ & 47.6 & $\begin{array}{l}\text { lfs } \\
\text { fs } \\
\text { fs }\end{array}$ \\
\hline 14 & $\begin{array}{r}0-13 \\
|3-6|\end{array}$ & $\begin{array}{l}\mathrm{A} \\
\mathrm{C} 1\end{array}$ & 47.6 & $\begin{array}{l}\text { Ifs } \\
\text { fs }\end{array}$ \\
\hline
\end{tabular}

†Horizon nomenclature and textural abbreviations are from Soil Survey Staff (1951)

*Field measurements
Table 2 Particle-size distribution on clay-free basis for the top $3 \mathrm{~m}$ at site 5

\begin{tabular}{lcccc}
\hline $\begin{array}{l}\text { Depth } \\
(\mathrm{cm})\end{array}$ & Fine & $\begin{array}{c}\text { Sands (\%) } \\
\text { Very fine }\end{array}$ & Coarse & Silts (\%) \\
\hline $0-15$ & 2 & 25 & 48 & 23 \\
$15-36$ & 2 & 30 & 46 & 21 \\
$36-48$ & 2 & 32 & 48 & 17 \\
$48-58$ & 2 & 40 & 44 & 13 \\
$58-89$ & 2 & 39 & 41 & 18 \\
$89-109$ & 4 & 38 & 39 & 18 \\
$109-127$ & 2 & 34 & 46 & 17 \\
$127-157$ & 1 & 10 & 50 & 37 \\
$157-178$ & tr & 8 & 49 & 42 \\
$178-208$ & tr & 10 & 47 & 42 \\
$208-229$ & tr & 10 & 50 & 40 \\
$229-264$ & 1 & 11 & 49 & 39 \\
$264-290$ & tr & 12 & 49 & 38 \\
$290-312$ & 1 & 16 & 47 & 36 \\
\hline
\end{tabular}

(1941), these surface textures indicate a source in the Arkansas River valley rather than the Cimarron River valley. Our results also support the findings of earlier investigators (Welch and Hale, 1987; Smith, 1940), who suggested that sources for sedimentation in this part of Kansas are predominantly from the north and northwest.

Simonett (1960), studying sand movement, investigated dune alignment south of the Arkansas River between Syracuse, Garden City, and Dodge City. He concluded that there is a weak tendency toward a south-southwest to north-northeast alignment of dunes, indicating winds blowing from the north. In addition, he showed that wind data from recording stations at Garden City and Dodge City had resultant sand movement vectors of $143^{\circ}$ for Garden City and $110^{\circ}$ for Dodge City. The $35^{\circ}$ difference was attributed to the short duration of both records, whose periods of record overlapped only partially. He concludes that winds had the greatest transport capabilities and thus dune-building capacity when blowing out of the north-northwest. This too, suggests an Arkansas River valley source. Information from wind-direction data, previous references, location of dune fields, configuration of the river valleys, and surface textures point to the Arkansas valley as the most likely source for loess between the Cimarron and Arkansas Rivers. A line was drawn transverse to the Arkansas River source on the southeast side of the channel near the town of Sutton, and the distance to each sample site measured. Thickness of the upper surficial unit was calculated as described earlier. A linear relation between thickness and $\log$ distance from source resulted (Figure 2). The $\log$ function describing this thickness distribution is:

$$
\mathrm{Y}=899.19-400.78 \log \mathrm{X} \quad \mathrm{r}^{2}=0.59
$$

where $\mathrm{Y}$ is the thickness of the loess in $\mathrm{cm}$ and $\mathrm{X}$ is the distance from source in $\mathrm{km}$. This relation, expressed by the general equation format, $y=b-a \log x$, is common for windblown silts or loess units (Olson and Ruhe, 1979; Ruhe, 1969; Smith, 1942) and fulfils one of the criteria for testing the validity of using the loessdistribution model. Handy (1976) suggests that this type of relation is the result of variable wind directions rather than prevailing winds. He also states that a moderate prevailing wind tends to preserve variable wind-induced semilog thickness relations on the downwind side of the source. Skidmore $e t$ al. (1994) demonstrate that the winds having the greatest capacity to move and redistribute material may not necessarily be the prevailing winds. From Simonett's (1960) vector diagrams, the presentday dune alignment throughout the area, and modern wind-direction data that show decided seasonal modality, it is likely that the 


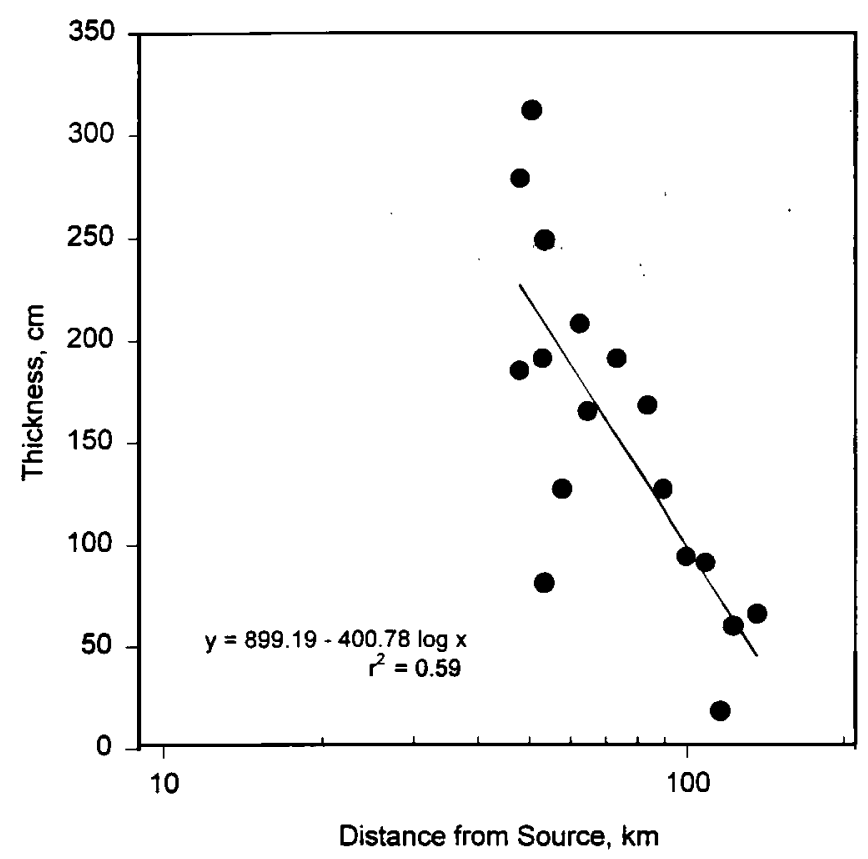

Figure 2 Loess thickness distribution with distance from the Arkansas River valley source.

winds producing these deposits were variable with erosive winds blowing commonly from the north.

The second test of the loess-distribution model is to examine particle-size distributions with distance from source. Figure 3 shows the distribution values for very fine sand, coarse silt, and fine silt plotted against distance. These data are more appropriately presented on a clay-free basis (Figure 3a) because the particle-size distribution of this stratigraphic unit as a whole is much coarser than loess units described to the east in Iowa, Illinois and Indiana, and because much of the unit is in the portion of the soil profile subject to pedogenic clay formation. However, the results for this particular study area do not differ greatly from those that include clay (Figure $3 b$ ), in part because clay illuviation is minimal. The lack of clay translocation seems to be a regional occurrence. We found few clay films in soils of similar age in nearby Morton County other than stress cutans. Fraser and Ransom (1989) also found little evidence of translocated clay in similar soils of western Kansas. In microscopic examination of clay films, Ransom et al. (unpublished data) suggest a stress (shrink and swell) rather than an illuvial origin for the clay films of soils in this region.

Particle-size distributions show a linear relation with distance from source: the very fine sand content decreases and the fine and coarse silt contents increase. The sites closest to the river do not seem to fit the model. At these sites, the upper surficial silty unit interfingers with dune sands and is eventually buried by these sands at sites nearest the river. Increasing amounts of very fine and coarser sands are present at these sites (Table 1). Because sands move by saltation rather than in suspension for any distance, sites having significant sand content cannot be described by the model developed for loess.

The thickness and particle-size distributions with distance from source have patterns approximating those that are known for loess, so the uppermost surficial unit in this study is considered to be loess. The correlation coefficients may seem somewhat low, in part because the loess is much coarser than that found in the Midwest, where many of these relations were first developed, and in part because the regressed values include those near the source. In addition, reworking of materials by variable winds from the south and southwest (Skidmore et al., 1994) may have perturbed slightly the sediment distribution with distance from source.
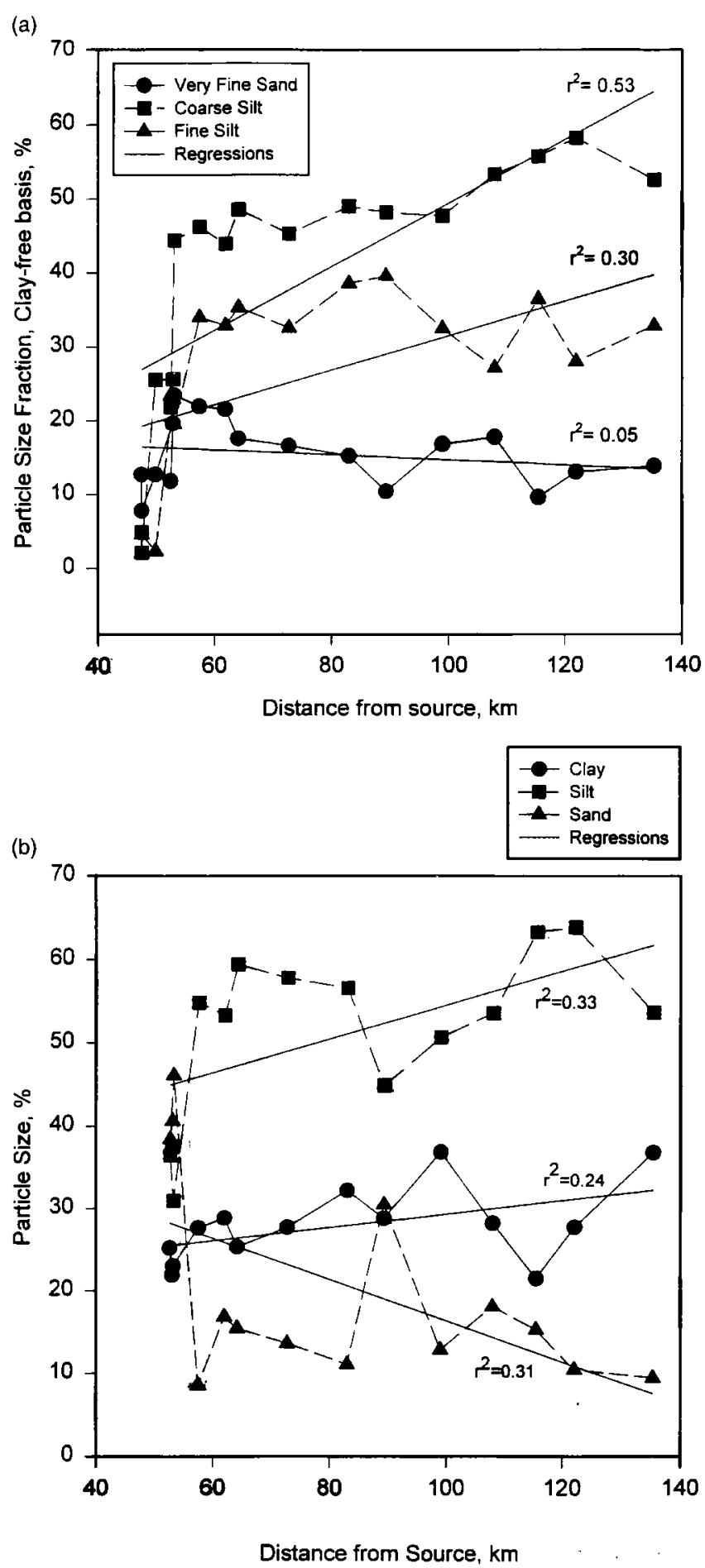

Figure 3 Particle-size distribution plotted against distance from the Arkansas River valley source: (a) clay-free basis and (b) total $<2 \mathrm{~mm}$-size basis.

\section{Holocene landscape evolution}

\section{Regional stratigraphic relations}

The generalized Holocene sequence in southwestern Kansas from oldest to youngest consists of the Brady soil, the Bignell Loess, aeolian sands or fluvial deposits, and the modern ground soil. A ground soil is the soil presently at the surface. An accepted date for the Holocene-Pleistocene boundary is about 10000 years (Hopkins, 1975). For west-central Kansas, this boundary is crossed by the Brady soil, a time-transgressive soil-stratigraphic unit (Schultz and Stout, 1948; Frye and Fent, 1947; Frye and Leonard, 1951).

The Brady soil is extensive only in northwestern and west- 
central Kansas, but even there its occurrence is discontinuous (Frye and Leonard, 1951). Johnson (1993) states that 'without an overlying stratigraphic unit the Brady soil does not exist'. More likely the Brady soil is present but is welded to (Olson and Hupp, 1986; Ruhe and Otson, 1980), or is the ground soil, and thus it is difficult to distinguish as a unique soil-stratigraphic unit.

The Bignell Loess overlies the Brady soil. If the Bignell Loess is the uppermost stratigraphic unit, it also contains the ground soil in its upper part. According to published radiocarbon ages for the Brady soil, the Bignell Loess is generally less than 9000 years old. Throughout western Kansas, if the Bignell Loess is not the surface stratigraphic unit, the Brady soil is overlain generally by aeolian sands or fluvial deposits dating from 6000 years ago (Johnson and Arbogast, 1993; Johnson, 1993; Mandel, 1994; Porter et al., 1995). Ground soils have developed in these deposits.

\section{Local stratigraphic relations}

From our data, the stratigraphy in much of the study area consists of an upper loess unit, overlying a palaeosol developed in sands. East of site 5, this same sequence consists of the upper loess unit overlying a palaeosol developed in silts that may be a second, lower loess unit. In coring, we did not penetrate the base of this underlying silt unit, so no determinations of its origin or boundaries could be made. In the immediate vicinity of the Arkansas River, the uppermost stratigraphic unit is dune sand rather than the loess unit. These dune sands are the same surficial sands described by Simonett (1960).

Buried soils were identified at several sample sites. At four sites, whole soil samples were collected for radiocarbon analysis from the palaeosol subjacent to the loess unit (Table 3). During field sampling, these buried soils were assumed to be the Brady soil. Johnson (1993) reports ages for the Brady soil in Kansas to be 10000 to $8000 \mathrm{BP}$. At site 16 , the $\mathrm{Ab}$ horizon is dated at $6760 \pm 70 \mathrm{BP}$ and is overlain by dunes. Nearby, at sites 17 and 13 , the dates obtained from the Bt horizons of buried truncated profiles are $6085 \pm 70$ and $6220 \pm 75 \mathrm{BP}$, respectively. The A horizons have been eroded from both profiles. These two sites are now overlain by dune sand. Site 5 is significantly further both from the other three sites and from the river than the other sites, and the palaeosol is buried by silts rather than by dune sand. The date obtained here from the truncated Bt horizon is $6220 \pm 70 \mathrm{BP}$. The palaeosols in this study are 3000 to 4000 years younger than the ranges reported for the Brady soil anywhere else, including the type location along the Platte River (Dreeszen, 1970; Johnson, 1993) and sites along the Republican River (Souders and Kuzila, 1990) in Nebraska, both north of this study area.

Simonett (1960) described a palaeosol that he called Brady in a boring south of Holcomb, Kansas, very close to our sites 13,

Table 3 Radiocarbon dates from four sample sites south of the Arkansas River

\begin{tabular}{rllll}
\hline & $\begin{array}{l}\text { Depth } \\
(\mathrm{cm})\end{array}$ & Horizon & $\begin{array}{l}{ }^{14} \mathrm{C} \text { years } \\
\pm 1 \sigma^{*}\end{array}$ & Laboratory number \\
\hline 5 & $127-157$ & $2 \mathrm{Btkb}$ & $6220 \pm 70 \mathrm{BP}$ & Beta -48107 \\
13 & $279-305$ & $2 \mathrm{Btb}$ & $6220 \pm 75 \mathrm{BP}$ & Beta -48108 \\
16 & $191-201$ & $2 \mathrm{Ab}$ & $6760 \pm 70 \mathrm{BP}$ & Beta -48109 \\
17 & $249-274$ & $2 \mathrm{Btb}$ & $6085 \pm 70 \mathrm{BP}$ & Beta -48110 \\
\hline
\end{tabular}

*These samples were analysed by AMS. $\sigma$ is one standard deviation representing a $68 \%$ probability. $\delta^{13} \mathrm{C}$ values are not given because reported values have been adjusted by ${ }^{13} \mathrm{C}$ for total isotope effects generated in both nature and during physical and chemical laboratory procedures. These effects cannot be decoupled. Reported values are corrected for all fractionation effects. Adjusted ages are normalized to -25 per mil $\delta^{13} \mathrm{C}$.
16 , and 17 . Without the availability of any radiocarbon dates, he noted, however, that the palaeosol appeared less developed than the typical Brady soil of northeastern and northern west-central Kansas as described by Thorp et al. (1951) and Frye and Leonard (1952). In all likelihood Simonett described the same soil we have dated here, rather than the Brady soil.

Can we discount contamination as a factor in the age determinations of the buried soils reported here? Younger carbon contamination can be mechanical, such as rootlet intrusion, or chemical, from the leaching of acids or bases. The impact of a given amount of contamination with modern carbon becomes twice as great for each half-life of range extension (Bradley, 1994). In this study, the radiocarbon ages were slightly more than one half-life. In addition, the relative amount of contamination affects the error in reporting ages. Bradley (1994) shows that for 5\% contamination by younger carbon, the error in radiocarbon years is $<500$ years; for $<10 \%$ contamination, it is less than 900 years. AMS, the technique used in this study, is less prone to contamination. Smaller samples are used than in conventional ${ }^{14} \mathrm{C}$ techniques. Given these generally inherent factors, contamination risk is low for our samples. In addition, the properties of the samples themselves preclude much possibility for contamination. As discussed earlier, clay translocation is minimal, indicating that little leaching has occurred. The organic carbon profiles above, in, and below the sampled horizons are low, generally $<0.3 \%$. Carbonates are present in or above only the sample from site 5. For the other three sites, the $\mathrm{pH}$ values for the samples are between 7.3 and 8.1 (1:1 soil to water paste) suggesting that $\mathrm{Ca}^{++}$and $\mathrm{Mg}^{++}$dominate the exchange complex of the soil profiles. Under these conditions, organic carbon is considered complexed and nonmobile (Jenny, 1980: 132; Stevenson, 1994: 367). Schaetzl and Sorenson (1987) show that postburial enrichment of organic matter from bases, including carbonate, is minimal below depths of $1.0 \mathrm{~m}$. All sites in this study were sampled at depths below $1.0 \mathrm{~m}$. The reported radiocarbon ages are similar regardless of the textures of the overlying horizons. All these factors provide little evidence for contamination.

Sites 16 and 17 represent the best arguments for possible contamination. Both sites are geographically closer to each other than to any of the other sites and should have the most similar ages. Site 17 is a truncated version of the complete buried profile found at site 16. The age for the Ab horizon at site 16 is $6760 \pm 70 \mathrm{BP}$ and that for the Btb horizon of the truncated profile is $6085 \pm 70$ BP. Assuming the proximity of these two sites allows us to examine these as a solum sequence, hypothetically the $\mathrm{A}$ and $\mathrm{B}$ horizons of the same soil, the radiocarbon ages show the $B$ horizon to be approximately 700 years younger than the A horizon, an unlikely occurrence. This difference could be attributed to contamination of the B horizon by younger carbon either before or after truncation. Interpolations from the graphs provided in Bradley (1994) show that younger carbon contamination could be as much as $7 \%$. If younger carbon contamination is related to truncation, the Btb horizon ages from the three sites 5, 13 and 17 , once corrected, would have ages more similar to that of site 16 . If contamination is not related to truncation, then the relative differences in ${ }^{14} \mathrm{C}$ ages between sites remain about the same but approximately 700 years older than those ages reported in Table 3 . The range in ages of the buried soils reported here and discussed below are still too recent for an age range associated with the Brady soil, whether one accepts the possibility of contamination or not. These ages for the buried soil do represent a middleHolocene period of soil development and landscape stability.

From the evidence presented here, the uppermost stratigraphic unit in the study area is a loess unit. Whether it is the Bignell Loess or some younger unit is less clear. Johnson (1993) postulates that Bignell Loess deposition occurred from about 9000 or 8000 years ago to about 5500 years ago. A second problem is that 
the Bignell Loess as defined lacks any palaeosols. The palaeosols described and dated in this study would necessarily have to be included if the loess unit is equivalent to Bignell Loess.

\section{Climatic implications}

Little has been written about periods of landscape stability during the middle Holocene in west-central Kansas. Early- and middleHolocene erosion and removal of sediment in small and mediumsized river valleys has been reported across much of the Midwestern United States (Bettis et al., 1984; Knox, 1983). Periods of soil development both earlier and later than middle Holocene have been documented in valleys of central and northern Kansas in concert with incision and sediment removal. These periods are all in phase with those in the Midwest (Mandel, 1994; Arbogast and Johnson, 1994; Johnson, 1993). However, Arbogast and Johnson (1994) describe an interval of soil formation occurring about 6800 $\mathrm{BP}$, referring to it as a 'yet poorly documented period of soil stability'. Mandel (1994) states that Holocene valley fills in the Pawnee River alluvial valley of Kansas are devoid of any indications of soil development from 7000 to 5000 BP. This hiatus in soil development is in the precise interval occupied by the soils dated in this study. The apparent out-of-phase chronology might be expected given that the soils dated in the Pawnee valley system are primarily on alluvial surfaces, whereas the soils dated in this study are on the High Plains surface, well away from the valley.

Given the ages of materials presented here, the aeolian unit is either a late phase of Bignell-age deposition separated from earlier deposition by a palaeosol, or a younger unit entirely. Bignell Loess deposition must have decreased in the area prior to 6700 $\mathrm{BP}$ to allow soil development followed by a truncation phase some time after $6700 \mathrm{BP}$. This stratigraphic sequence indicates that an aeolian phase was activated some time after soil development around 6700 years ago.

A shift towards a warm, dry climate occurred from 8000 to 5000 BP (Deevey and Flint, 1957; Bryson et al., 1970; Webb and Bryson, 1972; Kutzbach, 1987). Atmospheric circulation patterns changed from primarily meridional to zonal air flow, which restricted the incursion of moist tropical air into the Great Plains (Deevey and Flint, 1957; Knox, 1983; Jacobson et al., 1987; Holliday, 1989). As the climate became drier, ecosystem zones shifted eastward. Trees were replaced by tall and mixed grasses and eventually by sparser short grasses. Reduced vegetation cover would tend to increase erosion, particularly from hillslopes, especially during seasonal rains or heavy cloudbursts. Broad, nearly level interfluves associated with the High Plains surfaces would be among the least and last to be affected by backwearing of slopes as hillslopes eroded. A lag time between the interruption of soil-forming intervals on upper surfaces and that on surfaces within the valley is entirely possible. Thus ages of soils on upper surfaces would appear slightly out-of-phase with ages of soils on surfaces in valley alluvial systems. This concept is supported also by reports that palaeosols on Holocene alluvial fans debauching into large valleys of the upper Mississippi River valley system are dated around $6500 \pm 600 \mathrm{BP}$ (Bettis and Hoyer, 1986; Bettis et al., 1984).

Following an interval of soil development, dune reactivation began some time after 6700 BP. Buried soils at the sites closest to the Arkansas River are overlain by sands, and those farther east and south are overlain by silts that fit a loess-distribution model. These sands are the stratigraphic equivalent of the loess unit. Younger dunes are also present and in places overlie both of these units. The time for reactivation in the study area compares well with a dune reactivation period reported at about $5570 \mathrm{BP}$ in Morton County, Kansas, south of the Cimarron River (Porter et al., 1995 ) and one at about 5670 BP near Great Bend, Kansas (Arbogast, 1993). Three to four intervals of dune reactivation have been reported during the Holocene on a regional basis (Ahlbrandt et al., 1983; Holliday, 1989; Forman et al., 1992; Madole, 1995). Holliday (1989) refers to two aeolian pulses in the middle Holocene from about 6300 to $5000 \mathrm{BP}$ and from about 5000 to 4500 BP. Both the vertical and lateral distributions of surficial sediments in the study area clearly indicate alternating periods of aeolian activity and landscape stability from 7000 to 5000 years ago.

\section{Conclusion}

The results of this study agree well with the composition of the map units in the surficial geology maps prepared from investigations of previous workers in this region, but they do not agree with the ages of the surficial units. The uppermost stratigraphic unit examined at sites south of the Arkansas River is a loess unit that fits a loess-distribution model and therefore is of aeolian origin. Close to the Arkansas River, the loess is either overlain by or interfingers with dune sand. A soil immediately below this loess is radiocarbon dated as middle Holocene, having ages between 6000 and 6700 years. These ages have been shown to be appropriately defined. Possible contamination of the samples by younger carbon is precluded by the properties of the soils and depth of sampling. This dates the loess as middle Holocene or younger. The radiocarbon ages do not agree with those accepted for the development of the Brady soil and the deposition of Bignell Loess, the only Holocene loess unit recognized in the midcontinent. Additional investigation of Holocene stratigraphy in the Great Plains of the USA may be warranted.

A climatic shift in which aeolian processes dominate following a relative period of landscape stability is indicated by dune sands and loess deposits overlying palaeosols dated between 6000 and 6700 years BP. This shift has been reported from proxy data by several researchers in other areas of the southern Great Plains and may be significant in a regional context.

\section{Acknowledgements}

The authors wish to thank Cleveland Watts, Steven Graber, Stanley Glaum, James McDowell, Leo Klameth and Hannan LaGarry, without whose field assistance this work would not have been possible. Review comments by Douglas Wysocki, Richard Madole, and Vance Holliday are also greatly appreciated.

\section{Note}

Mention of trade names or commercial products in this article does not constitute endorsement or recommendation for use.

\section{References}

Ahlbrandt, T.S., Swinehart, J.B. and Maroney, D.G. 1983: The dynamic Holocene dune fields of the Great Plains and Rocky Mountain basins, USA. In Brookfield, M.E. and Ahlbrandt, T.S., editors, Eolian sediments and processes, Amsterdam: Elsevier Science Publishers, 379-406. Arbogast, A.F. 1993: Paleoenvironmental implications of buried soils in a south central Kansas lunette. In Johnson, W.C., compiler, Second International Paleopedology Symposium Guidebook, Kansas Geological Survey Open-file Report 93-30, 9-1 to 9-7.

Arbogast, A.F. and Johnson, W.C. 1994: Climatic implications of the late Quaternary alluvial record of a small drainage basin in the Central Great Plains. Quaternary Research 41, 298-305.

Bagnold, R.A. 1941: The physics of blown sand and desert dunes. London: Chapman and Hall, 1-265.

Bettis, E.A. and Hoyer, B.E. 1986: Late Wisconsin and Holocene 
landscape evolution in Saylonille Lake area, Central Des Moines valley, Iowa. Iowa Geological Survey Open-file Report 86-1, 330 pp.

Bettis, E.A., Hoyer, B.E. and Hajic, E.R. 1984; Alluvial/colluvial fan development in the American Midwest. American Quaternary Association 8th Biennial Meeting Program and Abstracts, 13

Bradley, R.S. 1994: Quaternary paleoclimatology. New York: Chapman and Hall, $1-472$.

Bryson, R.A., Baerreis, D.A. and Wendland, W.M. 1970: The character of late glacial and postglacial climate changes. In Dort, W., Jr and Jones, J.K., Jr., editors, Pleistocene and recent environments of Central Great Plains, Lawrence: University Press Kansas, 53-74.

Deevey, E.S. and Flint, R.F. 1957: Postglacial hypsithermal interval. Science $125,182-84$

Dreeszen, V.H. 1970: The stratigraphic framework of Pleistocene glacial and periglacial deposits in Central Plains. In Dort. W., Jr. and Jones, J.K., Jr., editors, Pleistocene and recent environments of Central Great Plains. Lawrence: University Press Kansas, 9-22.

Feng, Z. 1991: Temporal and spatial variations in the loess depositional environment of central Kansas during the past 400,000 years. $\mathrm{PhD}$ dissertation, Lawrence: University of Kansas, $250 \mathrm{pp}$.

Forman, S.L., Goetz, A.F.H. and Yuhas, R.H. 1992: Large-scale stabilized dunes on the High Plains of Colorado - understanding the landscape response to Holocene climates with the aid of images from space. Geology $20,145-48$

Fraser, S.H. and Ransom, M.D. 1989: Genesis of loess-derived soils of western Kansas: clay movement and carbonate accumulations. In Agronomy Abstracts, American Society of Agronomy Annual Meeting, Las Vegas, NV, 263.

Frye, J.C. and Fent, O.S. 1947: The late Pleistocene loesses of central Kansas. Kansas Geological Survey Bulletin 70, part 3, 29-52.

Frye, J.C. and Leonard, A.B. 1951: Stratigraphy of late Pleistocene loesses of Kansas. Journal Geology 59, 287-305.

- 1952: Pleistocene Geology of Kansas. Geological Survey Kansas Bulletin 99 .

Handy, R.L. 1976: Loess distribution by variable winds. Geological Society America Bulletin 87, 915-27.

Hamilton, V.L., Jantz, D.R., Lobmeyer, M.A., Markley, Q.L. and Swafford, W.R. 1968: Soil survey of Haskel County, Kansas. USDASCS, Washington, D.C.: US Government Printing Office.

Harner, R.F., Angell, R.C., Lobmeyer, M.A. and Jantz, D.R. 1965 Soil survey of Finney County, Kansas. USDA-SCS, Washington, D.C. US Government Printing Office.

Holliday, V.T. 1989: Middle Holocene drought on the Southern High Plains. Quaternary Research 31, 74-82.

Hopkins, D.M. 1975: Time stratigraphic nomenclature for the Holocene epoch. Geology 3, 10.

Jacobson, G.L., Web, T. III, and Grim, E.C. 1987: Patterns and rates of vegetation change during the deglaciation of eastern North America In Ruddiman, W.F. and Wright, H.E., editors, North America and adjacent oceans during the last deglaciation, Geology of North America DNAG. v. k-3, Boulder. CO: Geological Society of America, 425-46.

Jenny, H. 1980: The soil resource: origin and behavior. New York: Springer-Verlag.

Johnson, W.C. 1993: Surficial geology and stratigraphy of Phillips County, Kansas, with emphasis on the Quaternary Period. Technical Series 1. Kansas Geological Survey, 1-66.

Johnson, W.C. and Arbogast, A.F. 1993: Geologic map of Finney Countr. Kansas, 1:50,000. Lawrence: Kansas Geological Survey. No. 28A and $28 \mathrm{~B}$.

Knox, J.C. 1983: Responses of river systems to Holocene climates. In Wright, H.E., editor, Late-Quaternary environments of the United States, Minneapolis: University of Minnesota Press, Chapter 3, 26-41.

Kutzbach, J.E. 1987: Model simulations of the climatic patterns during the deglaciations of North America. In Ruddiman. W.F. and Wright, H.E. editors, North America and adjacent oceans during last deglaciation. Geology of North America, DNAG, v. K-3, Boulder, CO: Geological Society of America, 425-46.

Madole, R.F. 1995: Spatial and temporal patterns of late Quaternary eolian deposition, eastern Colorado, USA. Quaternary Science Reviews, 14. $155-77$.

Mandel, R.D. 1994: Holocene landscape evolution in the Pawnee River valley, southwestern Kansas. Kansas Geological Survey Bulletin 236. $1-77$.
Olson, C.G. and Hupp, C.R. 1986: Coincidence and spatial variability of geology, soils and vegetation, Mill Run Watershed, VA. Earth Surface Processes and Landforms 11, 614-29.

Olson, C.G. and Ruhe, R.V. 1979: Loess dispersion model, southwest Indiana, USA. Acta Geologica Academiae Scientiarum Hungaricae 22, 205-27.

Porter, D.A., Ransom, M.D. and Olson, C.G. 1995: Spatial variability of paleosols within Holocene and oider dunes, southwestern Kansas. Abstracts with Program, North Central-South Central Sec. Geol. Soc. Amer. Mtg. Lincoln, NE, 80.

Ross, J.A. 1991: Geological map of Kansas. Lawrence: Kansas Geological Survey, University of Kansas. Map M-23, scale 1:500 000

Ruhe, R.V. 1973: Background of model for loess derived soils in the upper Mississippi River Basin. Soil Science 115, 250-53.

1969: Quaternary landscapes in Iowa. Ames: lowa State University Press, 1-255.

Ruhe, R.V. and Olson, C.G. 1980: Soil welding. Soil Science 130, 132-39.

Schaetzl, R.J. and Sorenson, C.J. 1987: The concept of "buried" versus "isolated" paleosols: Examples from northeastern Kansas. Soil Science $143,426-35$

Schultz, C.B. and Stout, T.M. 1945: Pleistocene loess deposits of Nebraska. American Journal of Science 243, 231-44.

Seitlheko, E.M. 1975: Studies of mean particle size and mineralogy of sands along selected transects on the Llano Estacado. Master of Science Thesis, Lubbock: Texas Tech University, 1-69.

Simonett, D.S. 1960: Development and grading of dunes in western Kansas. Annals of the Association of American Geographers 50, 216-42. Skidmore, E.L., Tatarko, J. and Wagner, L.E. 1994: A climate data base for wind erosion prediction. Symposium on current and emerging erosion prediction technology, Soil and Water Conservation Society, $87-89$.

Smith, G.D. 1942: Illinois loess-variations in its properties and distribution. Illinois Agricultural Experiment Station Bulletin 490, 139-84.

Smith, H.T.U. 1940: Geologic studies in southwesteı Kansas. Kansas Geological Survey Bulletin 34, 1-244.

1953: Use of aerial photography for interpretation of dune history in Nebraska, USA. IV INQUA Congress, Rome, 1-7.

Soil Survey Laboratory Staff 1992: Procedures for collecting soil samples and methods of analysis for soil survey. Soil Survey Investigations Report No. I USDA-SCS. Washington, D.C.: US Government Printing Office.

Soil Survey Staff 1951: Soil survey manual. USDA-SCS, Handbook 18, Washington, D.C.: US Government Printing Office.

- 1993: Soil survey manual. USDA-SCS, Handbook 18, revised, Washington, D.C.: US Government Printing Office.

Souders, V.L. and Kuzila, M.S. 1990: A report on the geology and radiocarbon ages of four superimposed horizons at a site in the Republican River valley, Franklin County. Nebraska. Proceedings of the Nebraska Academy Sciences 65, 65.

Stevenson, F.J. 1994: Humus chemistry, genesis composition, reactions (second edition). New York: John Wiley and Sons, Inc.

Swineford, A. and Frye, J.C. 1951: Petrography of the Peoria loess in Kansas. Journal Geology 59, 306-23.

Thorp, J. and Smith, H.T.U. 1952: Pleistocene eolian deposits of the United States, Alaska, and parts of Canada. National Research Council Committee for the Study of Eolian Deposits, Geological Society of America, Scale 1:2 500000

Thorp, J., Johnson, W.M. and Reed, E.C. 1951: Some post-Pliocene buried soils of the central United States. Journal Soil Science 2, 1-19.

Tomasu, B.I. and Roth, W.E. 1968: Soil survey of Gray County, Kansas. USDA-Soil Conservation Service, Washington, D.C.: US Government Printing Office

Webb, T. III and Bryson, R.A. 1972: Late- and postglacial climatic change in the northern Midwest, USA: Quantitative estimates derived from fossil pollen spectra by multivariate analysis. Quaternary Research 2 , 70-115.

Welch, J.E. and Hale, J.M. 1987: Pleistocene loess in Kansas - status, present problems and future considerations. In Johnson, W.C., editor, Quaternary Environments of Kansas. Kansas Geological Survey Guidebook Series $5,67-84$. 